\title{
Genetic diversity of central and peripheral populations of Toona ciliata var. pubescens, an endangered tree species endemic to China
}

\author{
J. Liu, J.M. Jiang and Y.T. Chen \\ Research Institute of Subtropical Forestry, Chinese Academy of Forestry, \\ Fuyang, Zhejiang, China \\ Corresponding author: J.M. Jiang \\ E-mail: jiang_jingmin@163.com
}

Genet. Mol. Res. 13 (2): 4579-4590 (2014)

Received June 5, 2013

Accepted October 29, 2013

Published June 17, 2014

DOI http://dx.doi.org/10.4238/2014.June.17.10

\begin{abstract}
Our objective was to examine the genetic diversity of central and peripheral populations of Toona ciliata var. pubescens, to elucidate whether the central-peripheral hypothesis applies to these populations. We analyzed 392 individuals from nine natural populations using eight pairs of polymorphic SSR primers. The results showed that the mean numbers of observed and expected alleles in peripheral populations were higher than in central populations. Common widespread and rare local (RL) alleles were observed in all populations. However, common local alleles were found in five populations and rare widespread alleles were only found in three. The total numbers of the four types of alleles were higher in peripheral than in central populations, and the quantity of the RL allele was obviously higher in the peripheral populations than in the central populations. Both the observed and expected heterozygosities were higher in peripheral populations compared with the central populations. The coefficient of gene differentiation of the peripheral populations was 0.3045 , which was significantly higher than that of the central
\end{abstract}


populations. The gene flow between central populations was greater than one, but less than one between peripheral populations. This indicates that frequent gene flow exists between central populations, while terrain and habitat fragmentation prevent gene flow between peripheral populations. A Mantel test indicated that there was no relationship between genetic and geographical distance of $T$. ciliata var. pubescens.

Key words: Central population; Toona ciliata var. pubescens; Conservation strategies; Genetic diversity; Peripheral population

\section{INTRODUCTION}

Habitat fragmentation has a huge impact on plant reproduction success and the survival of populations (Grime, 1977; Goverde et al., 2002). The direct result of this is the loss of pollinators (Matsumura and Washitani, 2000) and the formation of central and peripheral populations (Wang et al., 2002). Central populations are usually large and continuous in their distribution, occupying suitable habitat conditions (Huang et al., 2005), while peripheral populations occupy less suitable habitats and are more sensitive to climate change. The response of species to environmental changes depends largely on the response of the populations inhabiting the periphery (Ledig, 1986). When conservation strategies on the genetic diversity of plants are formulated, only conservation of the central populations is generally considered, with that of peripheral populations being largely ignored (Coates, 2000; Channell and Lomolino, 2000). Therefore, against the backdrop of global climate change, studies on peripheral populations are extremely valuable (Lesica and Allendorf, 1995; Van Rossum et al., 2003).

Studies on the genetic structure of peripheral and central populations have become hot issues in the field of species conservation and evolution research. Based on the central-rich model, Mayr (1963) proposed the central-peripheral hypothesis. This hypothesis states that compared with central populations, peripheral populations are small and have experienced a severe bottleneck effect; genetic drift and selection pressure would lead to reduced genetic diversity with increased genetic differentiation eventually leading to extinction (Hampe and Petit, 2005). Although many studies on central and peripheral populations support the central-peripheral hypothesis, e.g., in Pinus rigida Mill (Guries and Ledig et al., 1982), Lychnis viscaria (Lammi et al., 1999), and Viola elatior (Eckstein et al., 2006), some controversies remain. Some researchers believe that migration from central populations can partly compensate for low density and reproductive success rates, thereby maintaining relatively high genetic diversity in peripheral populations (Kirkpatrick and Ravigne, 2002; Hampe and Petit, 2005). Hamann et al. (1998) and Gapare et al. (2005) conducted studies on Picea sitchensis (Bong.) Carr and Alnus rubra (Bong), respectively, and showed that because of high levels of gene flow between populations, their peripheral and central populations have high levels of genetic diversity.

Toona ciliata var. pubescens is a deciduous, broad-leaved tree species belonging to the genus Toona in the family Meliaceae. It grows rapidly, with a straight trunk, red 
heartwood, and beautiful wood grain, and it is known as Chinese mahogany. It is a valuable timber species with high economic value and development prospects. It is an economically and ecologically important native tree species in Southern China. Because of environmental change, logging, and slow natural regeneration, its numbers have gradually declined. T. ciliata var. pubescens is listed as a second-class state conservation endangered species endemic to China (Liu et al., 2008). It occurs naturally throughout a belt along a subtropical monsoon region over $2000 \mathrm{~km}$ from northeast Zhejiang Province through Jiangxi, Anhui, Fujian, Hubei, Hunan, Guizhou Provinces, and up to southwest Yunnan and Guangxi Provinces. The species is limited to the subtropical monsoon region. In northeast Zhejiang, Fujian, Anhui, and Jiangxi Provinces, the species has large and small populations. In southwest Guizhou, Guangxi and Yunnan Provinces, the range is more attenuated, and then becomes discontinuous. Based on the terrain and topography of its distribution area, vast areas to the south of the Dabieshan Mountains, north of the Nanling Mountains, and east of the Xuefeng Mountains extending to the eastern coast form the central populations of T. ciliata var. pubescens. These include the Xianju (XJ) population in Zhejiang Province, Nanping (NP) population in Fujian Province, Jingxian (JX) population in Anhui Province, and Yifeng (YF) population in Jiangxi Province. Those beyond the above range form the peripheral populations, mainly including the Yuanmou (YM) population in Yunnan Province, Enshi (ES) population in Hubei Province, Xiangxi (XX) population in Hunan Province, Baise (BS) population in Guangxi Province, and Ceheng $(\mathrm{CH})$ population in Guizhou Province. These populations provide good material for the study of the genetic diversity of central and peripheral populations of T. ciliata var. pubescens.

In this study, we employed microsatellite (SSR) marker techniques to elucidate the differences in genetic diversity between the central and peripheral populations of $T$. ciliata var. pubescens. We looked at the expected heterozygosity, the distribution of rare alleles within and between the populations, gene flow, inbreeding, and genetic differentiation to verify whether the conclusions of the central-peripheral hypothesis apply to T. ciliata var. pubescens, that is, whether or not the peripheral populations have low genetic diversity and high genetic differentiation.

\section{MATERIAL AND METHODS}

\section{Materials}

The field investigation on the nine T. ciliata var. pubescens populations in nine provinces were performed in 2011 using the direct sampling method (Eckert et al., 2008). The conditions and sampling quantity of the nine populations are shown in Figure 1. There were fewer individuals in the YF, XJ, NP, JX, YM, and XX populations, according to the investigation conditions where all individual plant materials were collected. There were more individuals in the $\mathrm{CH}, \mathrm{ES}$, and BS populations; at first, the distance between individuals was over $50 \mathrm{~m}$. Upper leaves were collected from individual trees and 392 individual samples were collected in total. The leaves were rapidly dried with silica gel; the ratio of silica gel to leaf was 10:1. The location of each individual sampled was recorded by GPS (Magellan, eXporist 600). 


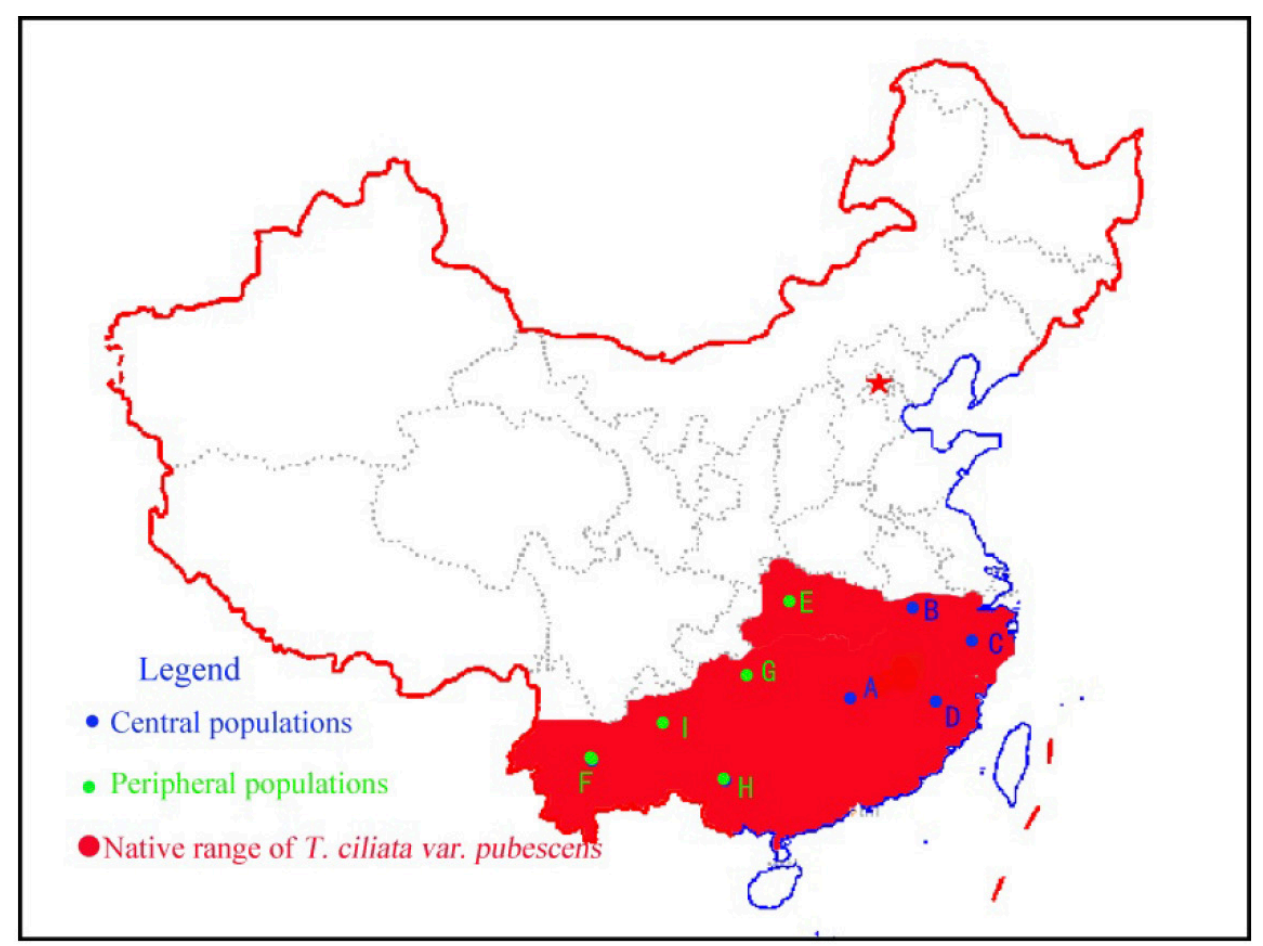

Figure 1. Native range of Toona ciliata var. pubescens and locations of populations sampled.

\section{Genomic DNA extraction and PCR}

Genomic DNA was extracted with the improved CTAB method (Liu et al., 2006). A $15-\mu \mathrm{L}$ reaction mix was used, comprising $1.5 \mu \mathrm{L} 10 \mathrm{X}$ buffer, $0.3 \mu \mathrm{L} 2 \mathrm{U} / \mu \mathrm{L}$ Taq, $2.5 \mathrm{mM}$ dNTP, $10 \mathrm{mM}$ primers, and $30 \mathrm{ng}$ template DNA. Amplification was performed with the MYCYLE PCR Apparatus (BIORED, USA). The reaction program was as follows: pre-denaturation at $94^{\circ} \mathrm{C}$ for $4 \mathrm{~min}$, then 35 cycles $\left(94^{\circ} \mathrm{C}\right.$ denaturation for $1 \mathrm{~min}, 52^{\circ}-55^{\circ} \mathrm{C}$ annealing for $0.5 \mathrm{~min}$, $72^{\circ} \mathrm{C}$ extension for $1 \mathrm{~min}$ ), and a final extension at $72^{\circ} \mathrm{C}$ for $10 \mathrm{~min}$. The eight SSR loci used have been previously designed and screened by our laboratory and feature good repeatability, clear and stable amplification bands (Table 1) (Liu et al., 2006). The PCR amplification product was added with about $5 \mu \mathrm{L}$ sampling buffer, and analyzed on an $8 \%$ polyacrylamide gel at $120 \mathrm{~V}$ for $3 \mathrm{~h}$. The electrophoretic buffer was $1 \mathrm{X}$ TBE. PCR amplifications were visualized by silver staining according to manufacturer guidelines (Promega, 1995). A 10-bp DNA ladder (Invitrogen, USA) was used as a size standard; gels were photographed with a digital camera (Canon, Japan).

\section{Data analysis}

The observed number of alleles $\left(N_{\mathrm{A}}\right)$, number of effective alleles $\left(N_{\mathrm{E}}\right)$, observed het- 


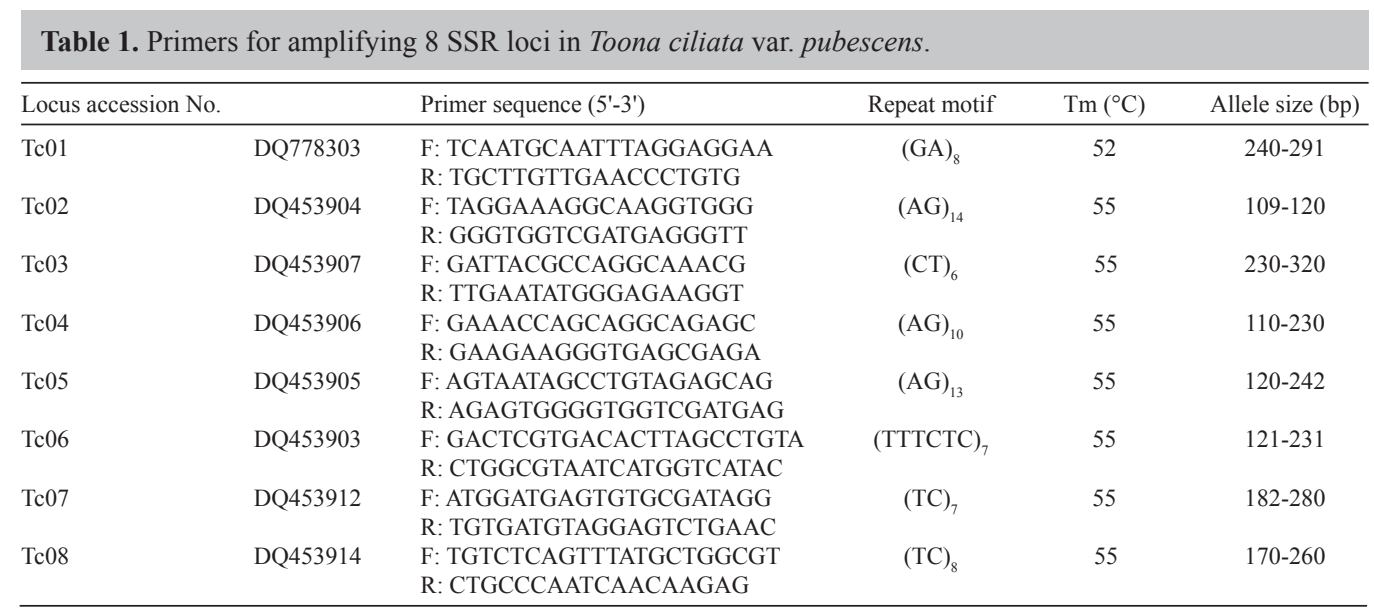

erozygosity $\left(H_{\mathrm{O}}\right)$, and expected heterozygosity $\left(H_{\mathrm{E}}\right)$ of various loci, inbreeding coefficient $\left(F_{\text {IS }}\right)$ and coefficients of gene differentiation $\left(F_{\mathrm{ST}}\right)$, and gene flow $\left(N_{\mathrm{m}}\right)$ of the populations were calculated with POPGENE32 (Yeh and Boyle, 1997). Analysis of molecular variance (AMO$\mathrm{VA}$ ) of the genetic variation between the central and peripheral populations was conducted with ARLEQUIN2.0 (Excoffier and Lischer, 2010). The significance of the genetic differentiation coefficient between populations was tested by TFPGA (Miller, 1997). Genetic structure was analyzed with STRUCTURE 2.2 (Pritchard et al., 2000).

According to the allele frequency and distribution within and between the populations, alleles were classified into four types (Marshall and Brown, 1975): common widespread allele (CW) (frequency $\geq 0.05$, existing in $\geq 25 \%$ of populations), common local allele (CL) (frequency $\geq 0.05$, existing among $\leq 25 \%$ of populations), rare widespread allele (RW) (frequency $\leq 0.05$, existing among $\geq 25 \%$ of populations), and rare local allele (RL) (frequency $\leq 0.05$, existing among $\leq 25 \%$ of populations). The allele frequency was calculated with GenAlEX 6.41 (Peakall and Smouse, 2006) to conduct statistics on the distribution conditions of various types of alleles among the populations.

\section{RESULTS}

\section{Number and distribution of alleles of natural populations of T. ciliata var. pubescens}

PCR amplification was performed for 392 individuals with eight SSR loci among nine natural populations of T. ciliata var. pubescens, and all eight primers were polymorphic. $N_{\mathrm{A}}$ per SSR locus varied from six to eight. Fifty-six observed alleles were detected among all populations and loci, and an average amplification of seven alleles per locus was observed. The average $N_{\mathrm{E}}$ was 3.01 . In the central populations, $N_{\mathrm{A}}$ was at least three and at most seven with the average being 4.75 , and the average $N_{\mathrm{E}}$ being 2.53 . For the peripheral populations, the average $N_{\mathrm{A}}$ was 6.38 and that of $N_{\mathrm{E}}$ was 2.87 (Table 2). 
Table 2. Observed $\left(N_{\mathrm{A}}\right)$ and effective $\left(N_{\mathrm{E}}\right)$ number of alleles in populations of Toona ciliata var. pubescens.

\begin{tabular}{|c|c|c|c|c|c|c|}
\hline \multirow[t]{2}{*}{ Loci } & \multicolumn{2}{|c|}{ All populations } & \multicolumn{2}{|c|}{ Central populations } & \multicolumn{2}{|c|}{ Peripheral populations } \\
\hline & $N_{\mathrm{A}}$ & $N_{\mathrm{E}}$ & $N_{\mathrm{A}}$ & $N_{\mathrm{E}}$ & $N_{\mathrm{A}}$ & $N_{\mathrm{E}}$ \\
\hline $\mathrm{Tc} 01$ & 6.00 & 3.37 & 3.00 & 1.98 & 5.00 & 3.64 \\
\hline Тc02 & 6.00 & 1.60 & 3.00 & 1.73 & 6.00 & 1.48 \\
\hline $\mathrm{Tc} 03$ & 6.00 & 2.57 & 4.00 & 2.94 & 6.00 & 2.27 \\
\hline Tc04 & 8.00 & 3.42 & 4.00 & 3.00 & 6.00 & 2.57 \\
\hline $\mathrm{Tc} 05$ & 8.00 & 3.36 & 3.00 & 2.93 & 8.00 & 2.57 \\
\hline $\mathrm{Tc} 06$ & 8.00 & 3.87 & 6.00 & 3.23 & 8.00 & 4.25 \\
\hline $\mathrm{Tc} 07$ & 8.00 & 3.44 & 7.00 & 2.58 & 8.00 & 4.06 \\
\hline $\mathrm{Tc} 08$ & 6.00 & 2.45 & 6.00 & 1.82 & 4.00 & 2.09 \\
\hline Mean & 7.00 & 3.01 & 4.75 & 2.53 & 6.38 & 2.87 \\
\hline Standard deviation & 1.07 & 0.74 & 1.58 & 0.59 & 1.51 & 1.00 \\
\hline
\end{tabular}

The distribution of the four types of alleles in nine populations of T. ciliata var. pubescens is shown in Figure 2. The CW alleles were present in all nine populations; these were the most frequent of the four types of alleles. $\mathrm{CW}$ alleles were highest in the YF population (CW $=23)$ and lowest in the $\mathrm{CH}$ population $(\mathrm{CW}=13)$. $\mathrm{CL}$ alleles were highest in the $\mathrm{CH}$ population but were absent in BS, XX, YM, and ES. The RW alleles only occurred in the YF, ES, and XX populations. The RL alleles were found in all nine populations of $T$. ciliata var. pubescens, and were highest in the ES population; only one RL allele was found in the $\mathrm{CH}, \mathrm{XX}$, and BS populations. Considering all four types of alleles, the ES and JX populations had the highest number of alleles, and the $\mathrm{CH}$ population had the least.

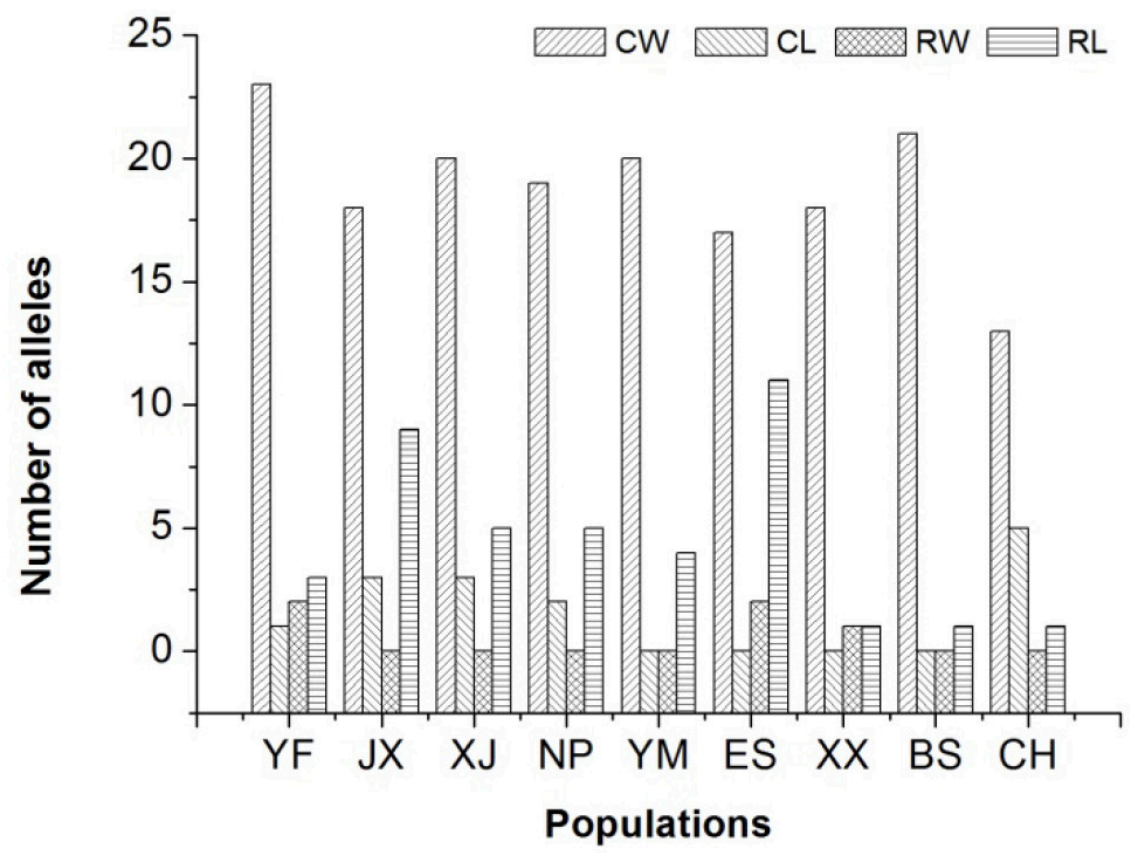

Figure 2. Distribution of different types of alleles in nine populations of Toona ciliata var. pubescens. $\mathrm{CW}=$ common widespread allele; $\mathrm{CL}=$ common local allele; $\mathrm{RW}=$ rare widespread allele; $\mathrm{RL}=$ rare local allele; $\mathrm{YF}=\mathrm{Yifeng}$;X = Jingxian; $\mathrm{XJ}=$ Xianju; $\mathrm{NP}=$ Nanping; $\mathrm{YM}=$ Yuanmou; $\mathrm{ES}=$ Enshi; $\mathrm{XX}=$ Xiangxi; $\mathrm{BS}=\mathrm{Baise} ; \mathrm{CH}=\mathrm{Ceheng}$. 


\section{Genetic diversity of natural populations of $T$. ciliata var. pubescens}

Heterozygosity is one of the best parameters to measure genetic variation in populations (Nei et al., 1975). Population genetic diversity is reflected in the average expected heterozygosity. Studies conducted by Takezaki and Nei (1996) showed that the range of the $H_{\mathrm{E}}$ for microsatellite loci was 0.3-0.8. Populations with higher genetic diversity have higher $H_{\mathrm{E}}$ (Li et al., 2006). In this study, the $H_{\mathrm{E}}$ of eight microsatellite loci was within the range of $0.3762-0.7426$ with the average being 0.6437 (Table 3 ); this is consistent with the results obtained by Takezaki and Nei (1996). The average $H_{\mathrm{E}}$ of the central populations was 0.5842 , while the average $H_{\mathrm{E}}$ of the peripheral populations was 0.6103 . The average $H_{\mathrm{E}}$ of different populations was $0.4304-0.6030$. The highest $H_{\mathrm{E}}$ was in the YM population $\left(H_{\mathrm{E}}=0.6030\right)$, and that of the BS population was the lowest $\left(H_{\mathrm{E}}=\right.$ 0.4304 ) (Table 4). The numerical regularity of Nei's $H_{\mathrm{E}}$ (Nei's) was consistent with that of the $H_{\mathrm{E}}$.

\begin{tabular}{|c|c|c|c|c|c|c|c|c|c|}
\hline \multirow[t]{2}{*}{ Loci } & \multicolumn{3}{|c|}{$H_{\mathrm{O}}$} & \multicolumn{3}{|c|}{$H_{\mathrm{E}}$} & \multicolumn{3}{|c|}{ Nei's } \\
\hline & $\begin{array}{c}\text { All } \\
\text { populations }\end{array}$ & $\begin{array}{c}\text { Central } \\
\text { populations }\end{array}$ & $\begin{array}{c}\text { Peripheral } \\
\text { populations }\end{array}$ & $\begin{array}{c}\text { All } \\
\text { populations }\end{array}$ & $\begin{array}{c}\text { Central } \\
\text { populations }\end{array}$ & $\begin{array}{c}\text { Peripheral } \\
\text { populations }\end{array}$ & $\begin{array}{c}\text { All } \\
\text { populations }\end{array}$ & $\begin{array}{c}\text { Central } \\
\text { populations }\end{array}$ & $\begin{array}{c}\text { Peripheral } \\
\text { populations }\end{array}$ \\
\hline $\mathrm{Tc} 01$ & 0.5911 & 0.2229 & 0.8458 & 0.7044 & 0.4964 & 0.7269 & 0.7035 & 0.4948 & 0.7253 \\
\hline $\mathrm{Tc} 02$ & 0.3542 & 0.5605 & 0.2115 & 0.3762 & 0.4258 & 0.3243 & 0.3757 & 0.4244 & 0.3236 \\
\hline $\mathrm{Tc} 03$ & 0.4922 & 0.5987 & 0.4185 & 0.6113 & 0.6615 & 0.5611 & 0.6105 & 0.6594 & 0.5598 \\
\hline $\mathrm{Tc} 04$ & 0.7839 & 0.8089 & 0.7665 & 0.7090 & 0.6695 & 0.6121 & 0.7081 & 0.6674 & 0.6107 \\
\hline Tc05 & 0.5042 & 0.5629 & 0.4615 & 0.7031 & 0.6614 & 0.6128 & 0.7022 & 0.6592 & 0.6113 \\
\hline Tc06 & 0.7659 & 0.7080 & 0.8148 & 0.7426 & 0.6930 & 0.7673 & 0.7413 & 0.6905 & 0.7650 \\
\hline Тc07 & 0.5224 & 0.3448 & 0.6579 & 0.7101 & 0.6142 & 0.7559 & 0.7090 & 0.6120 & 0.7539 \\
\hline $\mathrm{Tc} 08$ & 0.6730 & 0.4724 & 0.8085 & 0.5926 & 0.4522 & 0.5222 & 0.5917 & 0.4504 & 0.5208 \\
\hline Mean & 0.5859 & 0.5349 & 0.6231 & 0.6437 & 0.5842 & 0.6103 & 0.6427 & 0.5823 & 0.6088 \\
\hline
\end{tabular}

Table 4. Genetic diversity in populations of Toona ciliata var. pubescens.

\begin{tabular}{lccc}
\hline Population & $H_{\mathrm{O}}$ & $H_{\mathrm{E}}$ & Nei's \\
\hline YF & 0.5811 & 0.4920 & 0.4880 \\
JX & 0.4862 & 0.5023 & 0.4964 \\
XJ & 0.6103 & 0.4674 & 0.4548 \\
NP & 0.5019 & 0.5140 & 0.5029 \\
YM & 0.6692 & 0.6030 & 0.5899 \\
ES & 0.7596 & 0.5025 & 0.4977 \\
XX & 0.6848 & 0.4900 & 0.4805 \\
BS & 0.5926 & 0.4304 & 0.4276 \\
CH & 0.2143 & 0.4357 & 0.4266 \\
Mean & 0.5859 & 0.6437 & 0.6427 \\
\hline
\end{tabular}

\section{Genetic structure of natural populations of $T$. ciliata var. pubescens}

Wright (1965) established an $F$-statistical method to describe the degree differentiation of populations with three parameters $F_{\mathrm{IS}}, F_{\mathrm{IT}}, F_{\mathrm{ST}}$. Among these, $F_{\mathrm{ST}}$ is an important pa- 
rameter for detecting the degree of differentiation of populations and it is extensively used in the study of population genetic structure. $F_{\text {IT }}$ and $F_{\text {IS }}$ represent the inbreeding index of the overall level and individuals in single populations, respectively. The average value of $F_{\text {Is }}$ for the nine populations was -0.1631 (Table 5), indicating high heterozygosity and frequent genetic exchange between individuals. The average $F_{\text {IT }}$ value for all populations was 0.1750 , suggesting that the genetic exchange between the populations was infrequent, and the overall level of homozygosity in T. ciliata var. pubescens was higher. According to the results in Table 5 , the $F_{\mathrm{ST}}$ values of all loci were within the range of $0.0678-0.5601$, the average differentiation coefficient was 0.2907 . The genetic variation between populations accounted for $29.07 \%$ of the total variation of the populations and the degree of differentiation between various populations was high. The average value of the genetic differentiation coefficient $F_{\mathrm{ST}}$ for the central population was 0.152 , while that of the peripheral populations was 0.3045 , indicating greater differentiation in the peripheral populations. The genetic differentiation coefficient did not reach a significant level between the $\mathrm{CH}, \mathrm{YF}, \mathrm{NP}$, and XJ populations; however, it was significant between the other populations $(\mathrm{P}<0.01)$ (Table 6). AMOVA showed that there was significant genetic difference between the central and peripheral populations $(\mathrm{P}<0.05)$.

\begin{tabular}{|c|c|c|c|c|c|c|c|c|c|}
\hline \multirow[t]{2}{*}{ Loci } & \multicolumn{3}{|c|}{$F_{\text {IS }}$} & \multicolumn{3}{|c|}{$F_{\mathrm{IT}}$} & \multicolumn{3}{|c|}{$F_{\mathrm{ST}}$} \\
\hline & $\begin{array}{c}\text { All } \\
\text { populations }\end{array}$ & $\begin{array}{c}\text { Central } \\
\text { populations }\end{array}$ & $\begin{array}{c}\text { Peripheral } \\
\text { populations }\end{array}$ & $\begin{array}{c}\text { All } \\
\text { populations }\end{array}$ & $\begin{array}{c}\text { Central } \\
\text { populations }\end{array}$ & $\begin{array}{c}\text { Peripheral } \\
\text { populations }\end{array}$ & $\begin{array}{c}\text { All } \\
\text { populations }\end{array}$ & $\begin{array}{c}\text { Central } \\
\text { populations }\end{array}$ & $\begin{array}{c}\text { Peripheral } \\
\text { populations }\end{array}$ \\
\hline$\overline{\mathrm{Tc} 01}$ & -0.1585 & 0.4797 & -0.5316 & 0.3125 & 0.6036 & 0.0434 & 0.4066 & 0.2381 & 0.3754 \\
\hline $\mathrm{Tc} 02$ & -0.3160 & -0.4606 & -0.1579 & 0.0638 & -0.3495 & 0.3177 & 0.2886 & 0.0761 & 0.4108 \\
\hline $\mathrm{Tc} 03$ & 0.1149 & -0.0799 & 0.2857 & 0.2815 & 0.0765 & 0.4389 & 0.1883 & 0.1448 & 0.2145 \\
\hline $\mathrm{Tc} 04$ & -0.3975 & -0.4430 & -0.3569 & -0.0470 & -0.2678 & -0.0346 & 0.2508 & 0.1214 & 0.2375 \\
\hline $\mathrm{Tc} 05$ & -0.5859 & -0.7503 & -0.4372 & 0.3024 & 0.0343 & 0.3686 & 0.5601 & 0.4438 & 0.5607 \\
\hline $\mathrm{Tc} 06$ & -0.2351 & -0.0869 & -0.3722 & 0.0054 & -0.0340 & 0.0059 & 0.1947 & 0.0487 & 0.2755 \\
\hline $\mathrm{Tc} 07$ & 0.2670 & 0.4299 & 0.1598 & 0.3167 & 0.4525 & 0.2082 & 0.0678 & 0.0396 & 0.0577 \\
\hline $\mathrm{Tc} 08$ & -0.3936 & -0.1106 & -0.6203 & 0.1294 & -0.0414 & 0.0513 & 0.3753 & 0.0623 & 0.4145 \\
\hline Mean & -0.1631 & -0.1085 & -0.2099 & 0.1750 & 0.0600 & 0.1586 & 0.2907 & 0.1520 & 0.3045 \\
\hline
\end{tabular}

The range of $N_{\mathrm{m}}$ between two populations of $T$. ciliata var. pubescens was great; the maximum $N_{\mathrm{m}}$ between populations reached 46.046 and the minimum was 0.1798 (Table 6). The average, $N_{\mathrm{m}}$ among the nine natural populations was 0.610 , that of the central populations was 1.395 , and that of the peripheral populations was 0.5710 .

Table 6. Gene flow value (upper triangle) and $F_{\text {ST }}$ value (lower triangle) among populations of Toona ciliata
var. pubescens.
\begin{tabular}{llllllllrrr} 
Population & YF & JX & XJ & NP & YM & ES & XX & BS & CH \\
\hline YF & 0.0000 & 0.6178 & 1.4426 & 0.5477 & 0.7544 & 0.6509 & 46.0463 & 12.4404 & 0.2611 \\
JX & $0.2881^{* *}$ & 0.0000 & 0.8691 & 0.6499 & 0.6509 & 0.5673 & 0.6381 & 0.6913 & 0.3085 \\
XJ & $0.1477^{\text {ns }}$ & $0.2234^{* *}$ & 0.0000 & 0.9889 & 1.4718 & 1.0139 & 1.3115 & 2.1242 & 0.3013 \\
NP & $0.3134^{\text {ns }}$ & $0.2778^{* *}$ & $0.2018^{* *}$ & 0.0000 & 11.7692 & 3.9028 & 0.4740 & 0.6627 & 0.1905 \\
YM & $0.2489^{* *}$ & $0.2775^{* *}$ & $0.1452^{* *}$ & $0.0208^{* *}$ & 0.0000 & 7.8669 & 0.6664 & 0.9648 & 0.2203 \\
ES & $0.2775^{* *}$ & $0.3059^{* *}$ & $0.1978^{* *}$ & $0.0602^{* *}$ & $0.0308^{* *}$ & 0.0000 & 0.5872 & 0.7027 & 0.1798 \\
XX & $0.0054^{* *}$ & $0.2815^{* *}$ & $0.1601^{* *}$ & $0.3453^{* *}$ & $0.2728^{* *}$ & $0.2986^{* *}$ & 0.0000 & 4.7701 & 0.2574 \\
BS & $0.0197^{* *}$ & $0.2656^{* *}$ & $0.1053^{* *}$ & $0.2739^{* *}$ & $0.2058^{* *}$ & $0.2624^{* *}$ & $0.0498^{* *}$ & 0.0000 & 0.2553 \\
CH & $0.4891^{\text {ns }}$ & $0.4476^{\text {ns }}$ & $0.4535^{\text {ns }}$ & $0.5676^{\text {ns }}$ & $0.5316^{\text {ns }}$ & $0.5816^{\text {ns }}$ & $0.4927^{\text {ns }}$ & $0.4948^{\text {ns }}$ & 0.0000 \\
\hline
\end{tabular}

**P $<0.01 ; \mathrm{ns}=$ not significant. For abbreviations, see legend to Table 1. 
Genetic structure of T. ciliata var. pubescens was analyzed by using STRUCTURE 2.2. The results showed that nine populations were divided into five groups (Figure 3). The central populations of YF, NP and XJ belonged to a group, and the peripheral populations of $\mathrm{XX}, \mathrm{BS}$ and ES belonged to another group. The other three populations each comprised an individual group.

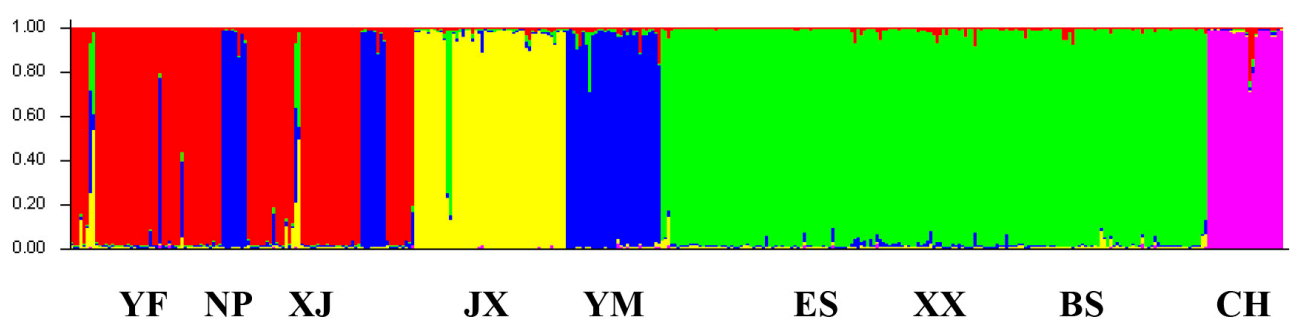

Figure 3. Estimated population structure of natural population for Toona ciliata var. pubescens. For abbreviations, see legend to Table 1 .

Genetic and geographic distance among natural populations of $T$. ciliata var. pubescens

The genetic distance of nine populations of T. ciliata var. pubescens was within the range 0.0134-0.9136 (Table 7). The genetic distance between the NP and $\mathrm{CH}$ populations was the largest, and that between the YF and XX populations was the smallest. A Mantel test indicated no relationship between genetic and geographical distance of T. ciliata var. pubescens $(\mathrm{r}$ $=-0.1077, \mathrm{P}=0.2490-0.7520)$.

Table 7. Genetic (lower triangle) and geographic distance (upper triangle) between natural populations of Toona ciliata var. pubescens.

\begin{tabular}{|c|c|c|c|c|c|c|c|c|c|}
\hline Population & YF & JX & $\mathrm{XJ}$ & NP & YM & ES & $\mathrm{XX}$ & BS & $\mathrm{CH}$ \\
\hline YF & 0.0000 & 466.5504 & 669.4126 & 522.6245 & 1582.3536 & 1438.1204 & 1371.0503 & 1220.4042 & 1000.2136 \\
\hline JX & 0.5458 & 0.0000 & 237.5536 & 123.7655 & 2042.5601 & 1898.9270 & 1831.9209 & 1683.5406 & 1464.7217 \\
\hline XJ & 0.2519 & 0.6742 & 0.0000 & 146.7940 & 2251.4805 & 2107.1323 & 2040.0699 & 1888.4254 & 1667.2401 \\
\hline NP & 0.5081 & 0.3900 & 0.4607 & 0.0000 & 2104.7085 & 1960.3726 & 1893.3087 & 1741.7866 & 1520.7142 \\
\hline YM & 0.4805 & 0.3403 & 0.4392 & 0.0710 & 0.0000 & 144.6144 & 211.5460 & 367.2899 & 589.4589 \\
\hline ES & 0.5249 & 0.3648 & 0.3951 & 0.1402 & 0.0741 & 0.0000 & 67.0702 & 223.4521 & 445.1481 \\
\hline XX & 0.0134 & 0.5143 & 0.3162 & 0.5381 & 0.5139 & 0.5547 & 0.0000 & 158.4894 & 378.9916 \\
\hline $\mathrm{BS}$ & 0.0461 & 0.6311 & 0.2206 & 0.5019 & 0.4753 & 0.5484 & 0.0922 & 0.0000 & 222.4602 \\
\hline $\mathrm{CH}$ & 0.7474 & 0.7489 & 0.7915 & 0.9136 & 0.8965 & 0.9570 & 0.7532 & 0.7312 & 0.0000 \\
\hline
\end{tabular}

\section{DISCUSSION}

\section{Genetic diversity of central and peripheral populations of $T$. ciliata var. pubescens}

The $H_{\mathrm{E}}$ of the central populations was lower than that of the peripheral populations, which indicated higher genetic diversity in peripheral populations. But no significant difference was found between central and peripheral populations by using the paired $t$-test (P 
$=0.2536$ ). These results do not agree with the central-peripheral hypothesis (Hampe and Petit, 2005). Possible reasons for the high genetic diversity observed in peripheral populations are: 1) T. ciliata var. pubescens is a long-living, deciduous tree species. The peripheral populations, such as YM and ES, have many ancient specimens, which contribute a large number of CW and RW alleles. According to the results of this study, the number of RW alleles in peripheral populations was significantly higher than that of central populations. The results are consistent with those of Gapare et al. (2005) regarding the RW alleles in the peripheral and central populations of North American spruces. 2) Van Rossum et al. (2003) conducted a study on allozyme variation of the central and peripheral populations of Silene nutans L. and discovered that both populations had high levels of genetic diversity, mainly related to their extensive distribution and great range of habitats. T. ciliata var. pubescens is widely distributed in subtropical regions from $24^{\circ}-30^{\circ}$, across northern, central, and southern subtropical regions. The climates and habitat conditions across its distribution vary greatly; for instance, the peripheral populations of T. ciliata var. pubescens located on the Yunnan-Guizhou Plateau is in the process of adapting to the high altitude habitat conditions, and it may evolve into different ecotypes or genotypes with different ecological characteristics, leading to rich genetic variations.

\section{Genetic structure and differentiation of $T$. ciliata var. pubescens populations}

The genetic differentiation coefficient was significantly different between the central $(0.1520)$ and peripheral populations $(0.3045)(\mathrm{P}<0.05)$, thus conforming to the prediction of the central-peripheral hypothesis that the genetic differentiation of peripheral populations is greater than that of the central population. The results were similar to those for $S$. nutans L. (Van Rossum et al., 2003) and P. sitchensis (Bong.) Carr (Gapare et al., 2005). Lesica and Allendorf (1995) proposed that species with weak dispersion ability are more susceptible in peripheral locations compared with species with long distance dispersion, since limited pollen and fruit dispersion reduce effective $N_{\mathrm{m}}$ and result in a high proportion of self-pollination leading to reduced $N_{\mathrm{m}}$. T. ciliata var. pubescens exhibits outcrossing insect-borne pollination with short dispersal distances and fruits spread by gravity. The peripheral populations of $T$. ciliata var. pubescens are located on the southwest Yunnan-Guizhou Plateau, with complex terrains and serious habitat fragmentation, resulting in low $N_{\mathrm{m}}$ between the peripheral populations $\left(N_{\mathrm{m}}=0.571\right)$. The central populations are located in the subtropical monsoon climate zone, which is affected by the southeast monsoon, so gene exchange between populations is frequent $\left(N_{\mathrm{m}}=1.395\right)$.

A Mantel test indicated no relationship between genetic and geographical distance of T. ciliata var. pubescens. Therefore, we suggest that terrain rather than geographical distance is the main cause of genetic differentiation between these populations. For example, the two populations of YM and XX in Yunnan province are geographically close, but because of the terrain and topography, the genetic differentiation between these populations is large.

\section{Strategies for the conservation of T. ciliata var. pubescens}

The main conservation strategies for forest genetic resources include in situ and ex situ conservation (Ledig, 1986). However, we believe the focus should be on in situ conserva- 
tion. In situ conservation is the conservation of the ecosystems and natural habitats as well as the maintenance and recovery of populations of species that play vital roles in the natural environmental state (White et al., 2007). In situ conservation of forest genetic resources is mainly achieved by establishing nature reserves. The Yukeng provincial, Wuyishan, and Guanshan National Nature Reserves have been established, which play a key role in the conservation of $\mathrm{XJ}, \mathrm{NP}, \mathrm{YF}$, and other central populations. In YM, XX, ES, and other peripheral populations, a large number of ancient $T$. ciliata var. pubescens trees are reserved; however, local people do not pay attention to them and they have poor conservation awareness. Implementing the protection and establishment of small nature reserves has been suggested. Ex situ conservation is supplementary to in situ. Populations are established and biodiversity components are protected outside of the natural habitat (White et al., 2007). Ex situ conservation should be combined with plantation management, tree breeding, and forest-introduction projects. According to this study, genetic variation in these populations accounts for $70.93 \%$ of the total variation; therefore, when performing ex situ conservation of $T$. ciliata var. pubescens, fewer populations should be selected and the sampling quantity within the population should be increased. Hamrick et al. (1991) proposed a method to estimate the number of populations that should be sampled for a species with the genetic differentiation coefficient $F_{\mathrm{ST}}$. If the number of the populations sampled is $\mathrm{n}$, then the ratio of genetic variation that was sampled is $1-\left(F_{\mathrm{ST}}\right)^{\mathrm{n}}$. In this study, the average coefficient of genetic differentiation between populations is 0.2907 ; therefore, more than three populations sampled can account for $97.5 \%$ of the total variance. As such, when performing sampling of natural populations and carrying out ex situ conservation of natural populations of $T$. ciliata var. pubescens, three populations with high levels of genetic diversity would suffice. In summary, our results indicate that the three populations of YM in Yunnan Province, NP in Fujian Province, and JX in Anhui Province are ideal for conservation and sampling.

\section{ACKNOWLEDGMENTS}

Research supported by the National Natural Science Foundation of China (\#31100487) and the Forestry Public Welfare Industry Research (\#201104001 and \#201204307).

\section{REFERENCES}

Channell R and Lomolino MV (2000). Dynamic biogeography and conservation of endangered species. Nature 403: 84-86. Coates DJ (2000). Defining conservation units in a rich and fragmented flora: implications for the management of genetic resources and evolutionary processes in south-west Australian plants. Aust. J. Bot. 48: 329-339.

Eckert CG, Samis KE and Lougheed SC (2008). Genetic variation across species' geographical ranges: the centralmarginal hypothesis and beyond. Mol. Ecol. 17: 1170-1188.

Eckstein RL, O'neill RA, Danihelka J, Otte A, et al. (2006). Genetic structure among and within peripheral and central populations of three endangered floodplain violets. Mol. Ecol. 15: 2367-2379.

Excoffier L and Lischer HEL (2010). Arlequin suite ver 3.5: A new series of programs to perform population genetics analyses under Linux and Windows. Mol. Ecol. Resour. 10: 564-567.

Gapare WJ, Aitken SN and Ritland CE (2005). Genetic diversity of core and peripheral Sitka spruce (Picea sitchensis (Bong.) Carr) populations: implications for conservation of widespread species. Biol. Conserv. 123: 113-123.

Goverde M, Schweier K, Baur B and Erhardt A (2002). Small scale habitat fragmentation effects on pollinator behaviour: Experimental evidence from the bumblebee Bombus veteranus on calcareous grasslands. Biol. Conserv. 104: 293-299.

Grime JP (1977). Evidence for the existence of three primary strategies in plants and its relevance to ecological and evolutionary theory. Am. Nat. 111: 1169-1194. 
Guries RP and Ledig FT (1982). Genetic diversity and population structure in pitch pine (Pinus rigida Mill). Evolution 36: $387-402$.

Hamann A, El-Kassaby YA, Koshy MP and Namkoong G (1998). Multivariate analysis of allozymic and quantitative trait variation in Alnus rubra: geographic patterns and evolutionary implications. Can. J. Forest Res. 28: 1557-1565.

Hampe A and Petit RJ (2005). Conserving biodiversity under climate change: the rear edge matters. Ecol. Lett. 8: 461-467.

Hamrick JL, Godt MJW, Murawski DA and Loveless MD (1991). Correlation Between Species Traits and Allozyme Diversity: Implication for Conservation Biology (Falk DA and Holsinger KE, eds.). In: Genetics and Conservation of Rare Plants. Oxford University Press, New York.

Huang Z, Liu N and Zhou T (2005). A comparative study of genetic diversity of peripheral and central populations of chukar partridge from Northwestern China. Biochem. Genet. 43: 613-621.

Kirkpatrick M and Ravigne V (2002). Speciation by natural and sexual selection: models and experiments. Am. Nat. 159 (Suppl 3): S22-S35.

Lammi A, Siikamäki P and Mustajärvi K (1999). Genetic diversity, population size and fitness in central and peripheral populations of a rare plant Lychnis viscaria. Conserv. Biol. 13: 1069-1078.

Ledig FT (1986). Conservation strategies for forest gene resources. Forest Ecol. Manag. 14: 77-90.

Lesica P and Allendorf FW (1995). When are peripheral populations valuable for conservation? Conserv. Biol. 9: 753-760.

Li L, Sun ZX, Yang SD, Chang LR, et al. (2006). Analysis of genetic variation of abalone (Haliotis discus hannai) populations with microsatellite markers. Hereditas 28: 1549-1554.

Liu J, Sun ZX, Chen YT, He GP, et al. (2006). Isolation of microsatellite DNA from endangered tree species Toona ciliata var. pubescens and optimization of SSR reaction system. China Biotechnol. 26: 50-55.

Liu J, Chen YT, Sun ZX, Jiang JM, et al. (2008). Spatial genetic structure of Toona ciliata var. pubescens populations in terms of spatial autocorrelation analysis. Sci. Silvae Sin. 44: 45-52.

Marshall DR and Brown ADH (1975). Optimum Sampling Strategies for Gene Conservation (Frankel OH and Hawkes JG, eds.). In: Crop Genetic Resources for Today and Tomorrow. Cambridge University Press, Cambridge, London, 53-80.

Matsumura C and Washitani I (2000). Effects of population size and pollinator limitation on seed-set of Primula sieboldii populations in a fragmented landscape. Ecol. Res. 15: 307-322.

Mayr E (1963). Animal Species and Evolution. Harvard University Press, Cambridge.

Miller MP (1997). Tools for Population Genetic Analysis (TFPGA). Version 1.3. Department of Biological Sciences, Northern Arizona University, Flagstaff.

Nei M, Maruyama T and Chakrorty R (1975). The bottleneck effect and genetic variability in populations. Evolution 29: $1-10$.

Peakall R and Smouse PE (2006). GENALEX 6: genetic analysis in Excel. Population genetic software for teaching and research. Mol. Ecol. Notes 6: 288-295.

Pritchard JK, Stephens M and Donnelly P (2000). Inference of population structure using multilocus genotype data. Genetics 155: 945-959.

Promega (1995). Technical Manual: Silver Sequence DNA Sequencing System. Promega Corp., Madison.

Takezaki N and Nei M (1996). Genetic distances and reconstruction of phylogenetic trees from microsatellite DNA. Genetics 144: 389-399.

Van Rossum F, Vekemans X, Gratia E and Meerts P (2003). A comparative study of allozyme variation of peripheral and central populations of Silene nutans L. (Caryophyllaceae) from Western Europe: implications for conservation. Plant Syst. Evol. 242: 49-61.

Wang YQ, Zhang ZB and Xu LX (2002). The genetic diversity of central and peripheral populations of ratlike hamster (Cricetulus triton). Chin. Sci. Bull. 47: 201-206.

White TL, Adams WT and Neale DB (2007). Forest Genetics. Chapter 10: Gene Conservation. CABI Publishing, Cambridge, 259-284.

Wright S (1965). The interpretation of population structure by F-statistics with special regard to systems of mating. Evolution 19: 395-420.

Yeh FC and Boyle TJB (1997). Population genetic analysis of co-dominant and dominant markers and quantitative traits. Belgian J. Bot. 129: 157. 